Modern Asian Studies 39, 3 (2005) pp. 509-533. (C) 2005 Cambridge University Press doi:10.1017/S0026749X04001659 Printed in the United Kingdom

\title{
Chinese Religion in English Guise: The History of an Illusion
}

\author{
T. H. BARRETT \\ School of Oriental and African Studies, University of London
}

The purpose of the following remarks is to trace the way in which, for over a century from the time of the first Opium War to that of the emergence of the study of Chinese religions as a separate specialization in the 1970s, the English-language world sustained a description of religion in China that was at very considerable variance with the facts. The narrative is not designed to be definitive-the choice of materials drawn upon is restricted, and somewhat arbitrary-but I trust that it ranges widely enough to explain just how this faulty analysis not only came into being but also managed to survive for so long. More detailed studies of aspects of the problem are already under way, and will doubtless appear in due course, but an overview at this point may even so be helpful. ${ }^{1}$ It may indeed even be helpful in the wake of the appearance of one such extremely detailed and valuable study, Norman Girardot's weighty volume on the towering figure of James Legge $\left(1815^{-1897)}\right.$. For while it is now possible to read an excellent study of Legge's views in the context of his own times-and no one interested in the topic treated here should ignore Girardot's research-a glance at the even broader context of the overall history of sinology in relation to Chinese religion suggests that Legge's views by and large fall into the more extended pattern outlined here. ${ }^{2}$ For rather than explore the outlook of any particular individual, the aim

\footnotetext{
${ }^{1}$ Some material from a long-term project in this area has already been published by Benjamin Penny, 'Meeting the Celestial Master', East Asian History 15/16 (1998), pp. 53-66, primarily with reference to Western views of Taoism; a London dissertation on modernity and Chinese Buddhism by Francesca Tarocco will deal with some aspects of the same problem, while a Princeton dissertation by Anna Xiaodong Sun will deal with Confucianism; a forthcoming publication by Eric Reinders on missionary constructions of Chinese religion has also been announced.

${ }^{2}$ See in particular Norman J. Girardot, The Victorian Translation of China: James Legge's Oriental Pilgrimage (Berkeley: University of California Press, 2002), pp. 298-331, though there are many sections of this immense work that serve to fill out the cursory survey offered here.
}

oo26-749X/05/\$7.50+\$0.10 
here is to illustrate, and to some preliminary degree explain, the persistence of a particular paradigm in the understanding of Chinese religion.

By 'extended pattern' I mean also that even making writings about China in English the object of an investigation is, of course, in itself somewhat arbitrary, since much was written on the topic throughout the period in other languages, and indeed the problematic nature of our materials lies precisely in their ultimate dependence on ideas formulated in another time and place elsewhere in Europe. Thus the Protestant Sinology of nineteenth-century Britain, despite a certain detectable spirit of independence, was heavily indebted at least in its early days to the Chinese studies long carried out by Jesuit missionaries, which came in the course of time predominantly to be published in French. ${ }^{3}$ Their influence in matters relating to the religions of China clearly persisted in direct form well into the late nineteenth century, especially as mediated through the French Jesuit author Jean-Baptiste Du Halde (1674-1743), of whom Benjamin Penny writes 'It is hard to escape the impression that Europeans in China at the beginning of the nineteenth century travelled with a copy of Du Halde's General History —or one of the several books that rely on it—so often are Du Halde's observations uncritically repeated'. And, one might add, not only at the beginning of the century, since Du Halde is specifically cited twice as a good source of information by A. E. Moule (1836-1918), in a work we shall be looking at that was published in $1871 .{ }^{5}$ The poet Ezra Pound, for that matter, while clearly not purporting to offer any direct firsthand observations of China, was still drawing on eighteenth-century Jesuit scholarship for his own knowledge of Chinese history as late as the mid-twentieth century. ${ }^{6}$

${ }^{3}$ The British belief that the Jesuits had misrepresented China, which surfaces already in the writings of Adam Smith as well as in the accounts of the Macartney and Amherst embassies, is still perfectly explicit in the 'Introduction' to Robert Fortune's account of his travels around China shortly after the first Opium War, cited below, as well as in the derogatory remarks on Catholicism also touched on in relation to Fortune. For Smith on 'stupid and lying missionaries', see David Martin Jones, The Image of China in Western Social and Political Thought (Basingstoke: Palgrave, 2001), p. 32 .

4 Penny, 'Meeting the Celestial Master', p. 57

${ }^{5}$ Arthur Evans Moule, Four Hundred Millions: Chapters on China and The Chinese (London: Seeley, Jackson and Halliday, 1871 ), pp. 8, 15 .

${ }^{6}$ This emerges from several of the contributions contained in Zhaoming Qian, (ed.), Ezra Pound and China (Ann Arbor: The University of Michigan, 2003): see pp. 91, 197,282 and 285 , the last two of which cover reminiscences from Pound's daughter. 
Thus if we are to understand the accounts of Chinese religion that started to appear in English in the nineteenth century, we must go all the way back to the first Jesuit encounter with China in the writings of Matteo Ricci (1552-1610). True, the Jesuit interpretation of Chinese religion was not a completely unchanging one, and many features of the eventual terminology used in describing China go no further back than the eighteenth century-the term 'neo-Confucian', for example. ${ }^{7}$ And not only that: Ricci, like the rest of his contemporaries, lacked much of the terminology in discussing religion that we take for granted, for example the very term 'religion' itself, in its current meaning. Sinologists, of course, are not the only students of civilization who have to put up with this inconvenience; scholars of religion dealing with the Greco-Roman world face an equally tricky task in tracing the origins of their own area of study through the semantic shifts of the languages we use. ${ }^{8}$ And naturally this does have some implications, as we shall see, for the specifically English-language materials we shall be examining. But for the most part it is not the precise terminology used by the Jesuits so much as the structure of their analysis that proved a particularly durable creation.

Much has admittedly been written already on Ricci and on his understanding of Chinese religion. ${ }^{9}$ For present purposes, however, there are two aspects of his work that need to be addressed. First, how did he divide up Chinese religion into separate categories? And secondly, how did he view his divisions in cultural space in relation to his perception of what might be termed 'cultural time'-that is, the ordering of history into larger patterns yielding culturally acceptable meanings? Insofar as his influence upon later scholars is concerned, the key document deriving from his observations on these topics may be found in the tenth chapter of the account of the Jesuit mission to

${ }^{7}$ According to D. E. Mungello, Curious Land: Jesuit Accommodation and the Origins of Sinology (Honolulu: University of Hawaii Press, 1989), p. 345, citing the research of Knud Lundbaek, this term probably appears for the first time in French in 1777 .

${ }^{8}$ See on this Jan N. Bremmer, "Religion", "Ritual" and the Opposition "Sacred vs. Profane": Notes towards a Terminological Genealogy', in Fritz Graf (ed.), Ansichten greichischer Rituale: Geburtstags-Symposium für Walter Burkert (Stuttgart and Leipzig: B. G. Teubner, 1998), pp. 9-32.

${ }^{9}$ Particular credit for identifying the relevance of Ricci for twentieth-century scholarship on Chinese religion must go to Jordan Paper, The Spirits are Drunk: Comparative Approaches to Chinese Religion (Albany: SUNY Press, 1995), pp. 4-12; my own observations are intended to go further to fill in the picture by adding references to nineteenth-century sources, and demonstrating wherever possible the filiations between sources, in order to show how Ricci's paradigm persisted. 
China up to 1610 published originally in Latin and then translated into French in $1616 .{ }^{10}$ Ricci's most immediate impact amongst learned circles in England might perhaps have been in the former language: one notes, for example, that Robert Burton (1577-1640), in his Anatomy of Melancholy, cites Ricci from the original Latin text. ${ }^{11}$ In the longer run, however, as we shall see, the French version appears to have had more staying power.

The chapter itself_-as transposed literally into English—is entitled 'Various Sects of False Religion Among the Chinese', which immediately illustrates the problem of shifting meanings just alluded to. ${ }^{12}$ For Ricci and his fellows there were but two religions: true religion, that in which he believed, and false religion, everything else, in an undifferentiated conglomeration of error. But, appearances to the contrary, he does have a reasonably objective way of differentiating other faiths. For underlying the word 'sect', or French 'secte', or Italian 'setta', is the Latin 'secta' which in classical usage means no more than 'something followed', and indeed thanks to a Latin summary of Ricci's most famous work in Chinese we can be absolutely sure that he used this word to represent the Chinese 'jiao', meaning a 'teaching', such as Buddhism. ${ }^{13}$ The pejorative meaning that adheres to the word 'sect' and its equivalent today was only picked up in the course of Reformation and Counter-Reformation in Europe: in early Elizabethan times, according to the Oxford English Dictionary, sub verbo, it was still possible to speak of 'Preaching the woord of Godd and sincere secte of Christe.' It is in this neutral sense, then, that we must understand Ricci's terminology in what follows.

Thus he first observes at the start of the chapter that of all peoples known to Europe, the Chinese had in the first centuries of their

10 The modern reprint follows a revised and corrected edition produced the following year in Lille, namely Matthieu Ricci et Nicholas Trigault, Histoire de l'expédition chrétienne au royaume de la Chine (1582-I6Io) (Paris: DDB/Bellarmin, 1978); another French edition appeared in Paris in 1618; the only complete English translation of Ricci as represented (or, as frequently, misrepresented) by Trigault was not produced until the twentieth century only a partial and loose translation of the Latin was carried out in the seventeenth century itself.

${ }^{11}$ Robert Burton, The Anatomy of Melancholy, First Partition (New York: New York Review of Books, 2001 reprint of 1932), pp. 255-6, 364-5, and notes on pp. $488,5^{10 .}$

12 Ricci/Trigault, Histoire, p. 160 , 'Diverses sectes de fausse religion entre les Chinois'.

${ }^{13}$ Compare Matteo Ricci, S.J., trans. Douglas Lancashire and Peter Hu Kuo-chen, S.J., ed. Edward J. Malatesta, S.J., The True Meaning of the Lord of Heaven (St. Louis: The Institute of Jesuit Sources, 1985), pp. 98-9 (Chinese, with English), and p. $4^{62}$ (Latin). 
antiquity fallen into the least error, for he read in their books that they had from the start adored a supreme and sole deity, whom they called the Lord of Heaven. ${ }^{14}$ But since nature unaided by grace tends to corruption over the centuries, this first light was so obscured that people fell if not into the worship of false gods then yet further into atheism. So in this chapter he will describe China's 'three sects': the books of the Chinese count 'three sects' in the world, for they do not know the others. The first is the sect of the literati, the second Shakyamuni, the third Laozi-in modern parlance Confucianism, Buddhism and Taoism. All the Chinese and their neighboursJapanese, Koreans, Ryukyuans and Cochin-Chinese (as we would say, Vietnamese) believe in one of these. ${ }^{15}$ Towards the end of the chapter, however, he adds four paragraphs modifying this picture. First, human vanity over the course of time has so corrupted matters that it would be better to speak of three hundred sects, or even to the further corruption of these three hundred to create a complete free for all. Secondly, the founder of the Ming dynasty had given priority to the sect of the literati, and had ensured recognition of the others, so that none tried to eliminate each other. Thirdly, there are idols everywhere in China, not only in the temples. Fourthly, some advocated the simultaneous observance of the three 'laws' (evidently a synonym for 'sects'), but since this was clearly impossible to do sincerely, they fell into complete 'lawlessness'-in short, into atheism. ${ }^{16}$

Now Ricci as presented to posterity in this fashion is plainly somewhat less sophisticated than Ricci as he is revealed in his then unpublished ipsissima verba. Jonathan Spence observes, for example, that whatever his initial impressions, he came to appreciate both that the educated and the uneducated held views at least as distinct as those of the ancient Epicureans and Pythagoreans, and that adherence to Confucianism could be reconciled either with Buddhism or Taoism. ${ }^{17}$ But the damage was done, in two different ways. We should of course admit that the idea of the ancient Chinese as monotheists

${ }^{14}$ Ricci/Trigault, Histoire, pp. 160-1.

${ }_{15} \mathrm{Ricci} /$ Trigault, Histoire, p. 161.

${ }^{16}$ Ricci/Trigault, Histoire, pp. 172-3. For a fuller account of Ricci on Chinese religion that gives due attention to the underlying patterns manifested in his thought, see David Porter, Ideographia: The Chinese Cypher in Early Modern Europe (Stanford: Stanford University Press, 2002), pp. 90-108; Porter pays particular attention to the concept of legitimacy.

${ }^{17}$ Jonathan Spence, The Memory Palace of Matteo Ricci (London; Faber and Faber, 1900), pp. $116-17$. 
was a very beguiling one, and one that beguiled Protestants as well as Catholics well into the twentieth century. ${ }^{18}$ But when one welldistributed and frequently reprinted popular modern biography of Ricci simply restates his belief that 'the doctrine of Confucius ... was in its original form monotheistic', we should not believe it for an instant. ${ }^{19}$ The discovery from about a century ago of new source materials on early China in the form of the so-called 'oracle bones' has taught us more about that distant age's religious beliefs than later Confucian Chinese-and perhaps missionaries too-would have been comfortable with. ${ }^{20}$ It has become quite clear that the high god of early China did not rule alone but shared the pantheon with a 'loose cluster of High Powers', going as far back as our sources will allow. ${ }^{21}$ Even worse, these not quite monotheists plainly practised regular human sacrifice on a scale inviting comparison with the Aztecs and other enthusiastic takers of human life. ${ }^{22}$ Of course, anyone can make mistakes about early history when the evidence is lacking, but for present purposes Ricci's decision to see subsequent religion as marking various stages of decline from a much higher level turned out to have particularly unfortunate consequences. Here, too, one may plead mitigating factors, in that Chinese writers also often thought in terms of 'deterioration from unity and oneness to plurality and distinction', to quote a description by Roger Ames of an essay from the Former Han. ${ }^{23}$ Nor, for that matter, was Ricci even the first Renaissance European to ascribe monotheism to the Chinese, since Fernão Mendes Pinto (1509-83) had already done this in his supposedly autobiographical

${ }^{18}$ For one eminent Protestant example from the twentieth century, see Lian Xi, The Conversion of Missionaries: Liberalism in American Protestant Missions in China, I9071932 (University Park, Pennsylvania: Pennsylvania State University Press, 1997), p. 179, on Bishop James W. Bashford, writing in 1914.

19 Vincent Cronin, The Wise Man from the West (London: Reader's Union, 1956), p. 95-this was the first popular edition of a work first published by Rupert Hart-Davis in 1955 and republished as recently as London: Harvill Press, 1999, with several other mass editions in between.

${ }^{20}$ And, as Girardot notes, Victorian Translation, p. 442, the idea of degeneration from original monotheism was also losing its sheen in academic circles in the study of religion at the same time.

${ }^{21}$ Thus David N. Keightley, concluding his overview of the matter in Michael Loewe and Edward Shaughnessy (eds), The Cambridge History of Ancient China (Cambridge: Cambridge University Press, 1999), pp. 252-5.

${ }^{22} \mathrm{~A}$ good and thoughtful account of this phenomenon is provided by Gideon Shelach, 'The Qiang and the Question of Human Sacrifice in the Late Shang Period', Asian Perspectives 35.1 (1996), pp. 1-26

${ }^{23}$ Roger T. Ames, The Art of Rulership: A Study of Ancient Chinese Political Thought (Albany, NY: SUNY Press, 1994), p. 14. 
account of his own mid-sixteenth century travels in China, albeit probably for very different motives. ${ }^{24}$ We might even add that Pinto also managed in this respect to lead astray at least one of his twentiethcentury editors. ${ }^{25}$ But Ricci's unpublished insight into the different character of belief amongst the educated and the unlettered would have served as a better guide to Chinese religion than the assumption that what he saw before him had come about as a result of the debasing of some single phenomenon far more worthy of admiration.

Indeed, one might today point to a possible reverse process, and in the light of modern research into the effects of literacy suppose that the relative unity of religious norms amongst the educated was the outcome of a standardization and narrowing of something that would otherwise have always been much more diverse: Jack Goody writes, for example, of confusion as the 'natural' condition of oral religion. ${ }^{26}$ Be that as it may, Ricci's understanding of religion over time, tied as it undoubtedly was to his strategy of trying to take over Chinese civilization at the top, resulted in his complete dismissal of Chinese popular religion from view in favour of the three relatively far less influential forms of tradition that presented themselves in writing. What was to him the most recent and most corrupt form of false religion, the so-called 'idolatry' of the mass of the population, might otherwise from a more neutral position be construed as the most ancient and also the most vigorous, the most capable of constantly dynamic growth and change. But that simply was not a view available to

${ }^{24}$ Mendes Pinto's motivations are not easy to fathom: Jonathan Spence follows recent research in concluding that his China is largely imaginary, despite his long residence in Asia and access to the firsthand information of others: see his review of the work of Rebecca Catz, reprinted in his Chinese Roundabout: Essays in History and Culture (New York: Norton, 1992), pp. 25-36, and his more recent summary in The Chan's Great Continent (London: Penguin, 1998), pp. 27-31, suggesting that his fictions, like so many after him, use China to offer some oblique comments on Europe.

${ }^{25}$ See C. D. Ley (ed.), Portuguese Voyages, I498-I663 (London; Phoenix Press, reprint of the Everyman, 1947 edition), p. 81. It is, perhaps, just possible that Europeans at this point genuinely found a respectably advanced polytheistic civilization something of a baffling contradiction in terms. One notes, for example, that when Mendes Pinto wishes to switch to castigating Chinese polytheism he points (evidently on the basis of his experience of Japan) to the four main Buddhist cultic figures Shakyamuni, Amitabha, Jizang and Guanyin, but then ascribes a separate religious doctrine to the devotees of each of them: cf. Ley, ibid., pp. 155, 172. Thankfully, perhaps, though Mendes Pinto was widely read in late seventeenthcentury Britain, he was not taken as a reliable authority: cf. Ley, p. xiv; Spence, Chinese Roundabout, p. 26.

${ }^{26}$ Jack Goody, The Logic of Writing and the Organization of Society (Cambridge: Cambridge University Press, 1986), p. 30. 
the late sixteenth-century mind, and even less so to those later, notably Protestant Europeans who preferred to see the story of Chinese civilization not even as one of greatness corrupted, but simply as a wearisome record of complete stagnation. ${ }^{27}$

All in all, then, despite his many other achievements, Ricci's published legacy to later Sinologists in the field of the study of religions was not as helpful as one might have wished. In terms of cultural time, he had divided the development of China into early monotheism, the later three religions, and unspeakable corruption. In terms of cultural space, he divided the cultural landscape that he himself saw, like Caesar surveying Gaul, into three parts only: there were the three teachings, and nothing else was known to the Chinese. His influence is easily detectable, of course, in the later Jesuit scholarship of the sixteenth century: Athanasius Kircher (1602-1680), in his famous China Illustrata of $\mathbf{1 6 6 7}$, uses the published version of Ricci's work more or less verbatim, interlarded with his own speculations about the relationship between Chinese and Egyptian religion, plus one or two details from a later Jesuit source. ${ }^{28}$ But is this really what we find in the independently minded British writers of China who appeared on the scene in the early nineteenth century?

It would not be surprising if the very earliest of these betrayed a somewhat bookish cast, in that the first British missionaries to the Chinese world were with one or two exceptions stalled for a generation outside China proper in the overseas Chinese world of South-East Asia. ${ }^{29}$ It was one former member of this group, Samuel Kidd (1799-1 843) who achieved the distinction, after being invalided home, of serving as the first Professor of Chinese in a British college, at University College, London, from 1837. When the results of his researches were published in 1843 , he had this to say about Chinese religion: 'The designations philosophical, fabulous and political, applied to the prevailing forms of superstition in China, may serve to point out their distinctions: although neither of these appellations is exclusively appropriate to any one of the Chinese systems, of which it is well

27 On this phenomenon, see most recently David Martin Jones, Image of China, pp. $67-98$.

${ }^{28}$ For the passage and its context in English, see Athanasius Kircher, trans. Charles D. Van Tuyl, China Illustrata (Bloomimgton, Indiana: Indiana University Research Institute for Inner Asian Studies, 1987), pp. 122-3. The importance of Kircher's work is explained e.g. by Mungello, Curious Land, pp. 134-173.

${ }^{29}$ On this episode, see Brian Harrison, Waiting for China (Hong Kong: Hong Kong University Press, 1979), especially pp. 79-83 for the missionary cited here. 
known, the three principle are, the sect of Reason, the sect of Fuh, and the sect of the Learned'-in other words, Taoism, Buddhism and Confucianism. Here the word 'sect', apparently indirectly inherited from Ricci, is by no means neutral, and just in case one might hope that the word 'principle' indicates some inkling of other forms of religionperhaps based on his direct observation of the overseas Chinese-then alas after three brief sentences describing each he starts again 'Since these sects are recognised by the state, and their votaries constitute almost the entire mass of its subjects...'-thus following precedent to the letter and denying himself the very interesting possibility of commenting on Chinese religion as he had known it, well beyond the reach of the state, and little touched by written traditions. ${ }^{30}$

The degree to which Kidd was directly drawing on Jesuit sources is unfortunately deliberately obscured in his work: his professorship was associated with a library of Chinese books collected by the missionary pioneer Robert Morrison (1782-1834)—the others had remained in East Asia-and so he was obliged to represent his knowledge as gleaned entirely from these sources. ${ }^{31}$ His own account of the Jesuit missions is very brief, a mere paragraph. ${ }^{32}$ Yet he is careful to characterize the high god of ancient China in a way that implicitly rejects the solution adopted by the Jesuits to their own missionary problems. Rather, he states that terms like 'Supreme Ruler' and 'Heaven' are used in the early sources 'to point out the all-controlling energy to which the actions of individuals, and the fate of nations, are subjected; which energy seems in many respects equivalent to the Jupiter Optimus Maximus of the ancients, both in the prerogatives it assumes and the attributes with which it is invested'. ${ }^{33}$ We should recall that educated Britons of the nineteenth century-and beyondwould have known enough about the ancient Mediterranean world to be able to appreciate such useful analogies: as we shall see, this was

30 Samuel Kidd, China (London: Taylor and Walton: 1841 ), p. 140.

${ }^{31}$ For Morrison's Chinese library, see Andrew C. West, Catalogue of the Morrison Collection of Chinese Books (London: SOAS, 1998); p. [vii] notes the survival of his European books in Hong Kong University as its own Morrison Library. Suzanne Wilson Barnett, in n. 5, p. 131, of her useful study 'Protestant Expansion and Chinese Views of the West', Modern Asian Studies6.2 (1972), pp. 129-49, apparently mistakes Kidd's Catalogue of the Chinese Library of the Royal Asiatic Society (London: John W. Parker, 1838), for a catalogue of Morrison's books, but does point out significantly that Kidd lists works by Roman Catholic missionaries there, though there is of course no guarantee that he read what he catalogued.

${ }^{32}$ Kidd, China, p. 157.

${ }^{33}$ Kidd, China, p. 148. 
not the last time that such analogies were pressed into service in trying to convey the nature of China's alien belief system.

Kidd was, in any case, preceded into print by a much better qualified observer of China, an East India Company employee in East Asia since 1815 who eventually rose to become the first governor of Hong Kong, Sir John Francis Davis $\left(1795^{-1} 890\right)$, whose own work on China and the Chinese first appeared in 1836 . Davis was certainly no slave to precedent: as far as I have been able to discover, he is the first person to use the word 'Confucianism' in English, twenty-six years before the source given sub verbo by the Oxford English Dictionary and followed by most writers on the history of comparative religion. ${ }^{34}$ His remarks on the topic of religion further show a desire to put the Chinese point of view: 'When a Chinese is asked how many systems of philosophic or religious belief exist in his country, he answers Three-namely $Y u$, the doctrine of Confucius, already noticed; $F_{0}$, or Budhism; and the sect of Taou, or "Rationalists". ${ }^{35}$ If Davis cannot resist the word 'sect' for what we now call Taoism, this may be because from the time of the Jesuits onwards out of the three it always received much the worst press in Europe. ${ }^{36}$ And of course his reports of the Chinese viewpoint are not inaccurate, for the word jiao, which we have mentioned above as meaning a teaching such as Buddhism, was never applied to the observances of the illiterate majority, and was only used once to my knowledge in the eighteenth century to describe the broader religion of the populace, specifically in the form in which it appeared textually in popular literature. ${ }^{37}$

Davis does show, too, some awareness that the three named traditions did not encompass the totality, in saying in the next chapter, which is at first devoted to Taoism, 'It remains for us to describe a variety of superstitious customs and observances which are practised by the Chinese, either with or without a particular relation to some one of the three sects, or persuasions, which have been already noticed' ${ }^{38}$

${ }^{34}$ John Francis Davis, The Chinese: A General Description of the Empire of China and its Inhabitants, Volume II (London: Charles Knight \& Co., 1836), p. 45 .

${ }^{35}$ Davis, The Chinese, II, p. 74 .

${ }^{36}$ This is noted for example by J.J. Clarke, The Tao of the West: Western Transformations of Taoist Thought (London; Routledge, 2000), pp. 38-9; cf. Girardot, Victorian Translation, p. 318 .

${ }^{37}$ See pp. ${ }^{1} 5^{8-9}$ of T. H. Barrett, 'Religious Traditions in Chinese Civilization: Buddhism and Taoism', in Paul S. Ropp (ed.), Heritage of China: Contemporary Perspectives on Chinese Civilization (Berkeley: University of California Press, 1990), pp. 138-63.

${ }^{38}$ Davis, The Chinese,II, p. 129. 
But this effort at thinking outside the categories provided for him is not sustained, for a couple of pages later, writing on the topic of talismans, he begins 'The general proneness of the Chinese to superstitious practices (most of which pertain to the Taou sect)...'thus showing how, once one followed the Jesuit lead in taking against the Taoists, it was possible to bundle any other form of religion which one disliked, or found too confusing to analyse, into the same capacious grab-bag. ${ }^{39}$

In this case we can certainly point to the possibility of tacit Jesuit influence, though overtly our author is at pains to distance himself from their views. His summary of the disputes of the 'Romish fathers' over the Chinese knowledge of the 'true Creator' ends on the observation that they have 'generally viewed the moral and religious character of the people in a somewhat prejudiced light'. ${ }^{40}$ But his list of authorities on whom he draws for his two small volumes includes many Jesuit works, starting with the French translation of Ricci as edited by Trigault that has been used above. ${ }^{41}$ So should we exonerate Davis too, on the grounds that though he spent many years in small trading enclaves, plus a brief foray to the capital as a junior member of the Amherst mission, he was obliged to rely mainly on earlier texts because after all he did not have much chance to see the real China, either?

Perhaps, but we cannot say the same for the generation that followed the First Opium War, after which China was forcibly opened up to foreign travellers, such as the remarkable plant collector, Robert Fortune (1812-1880), whose first reports of his 'wanderings among the Chinese' one might expect to have pioneered a new level of accurate description. ${ }^{42}$ And in a sense that is just what we get, for there is in his writing a quite palpable sense of deeply entrenched attitudes being challenged by the need to acknowledge the very positive character of his experiences in China. He takes issue, for example, with the missionary adventurer Karl Gutzlaff (18o3-1851), who had written in derogatory terms of Buddhism, which he found in appearance all too similar to the 'Romish church'. The many possible comparisons between the two clergies had indeed impressed

${ }^{39}$ Davis, The Chinese,II, p. 132.

${ }^{40}$ Davis, The Chinese,II, pp. 72-3.

${ }^{41}$ Davis, The Chinese, I, pp. 3-5.

${ }^{42}$ For a brief account of Fortune and his important place in the history of his chosen profession, see E.H. M. Cox, Plant Hunting in China (London: Collins, 1945), pp. $75^{-92 .}$ 
a number of others in earlier times-John Davis, for example, with the forthrightness typical of an era still not accustomed to Catholic emancipation, concludes on the matter 'To those who admit that most of the Romish ceremonies and rites are borrowed directly from paganism, there is less difficulty in accounting for the resemblance' ${ }^{43}$ Fortune's paragraph does not dwell on invidious comparisons, but rather ends: 'I am far from being an admirer of the Buddhist priesthood; they are generally an imbecile race, and shamefully ignorant of every thing but the simple forms of their religion, but nevertheless there are many traits in their character not unworthy of imitation'. ${ }^{44}$ And something of the same sense of prejudices in the course of being ameliorated by experience equally typifies his remarks on the Catholic missions of the day: 'although I do not approve of the doctrines which they teach, I must give them the highest praise for enthusiasm and their devotion to their faith'. ${ }^{45}$ All he has to say after his defence of his Buddhist hosts, however, is 'There are two other sects in China, namely, the followers of Kong-foo-tze or Confucius, and the sect of Taou or Reason. Although these three sects form the principal part of the population, it is well known that there are a great number of Mohammedans in every part of the empire...'-but though this last piece of information sounds novel, Ricci had followed up his own observations with a similar remark. ${ }^{46}$

Even so, Fortune is an interesting transitional figure, first amongst a number of nineteenth century writers on China in English who had ample opportunity to record what they saw through direct observation, with the result that their writings have been made available to modern scholars through reprints in order to try to provide ethnographic information on Chinese society in an age before the rise of fieldwork in social anthropology. There are obvious disadvantages to having to rely on this literature, much of which came from missionaries whose

${ }^{43}$ Davis, The Chinese II, p. 79. Girardot, Victorian Translation, p. 318, and nn. 96, 97, p. 673 ; p. 408, and n. 19, p. 707; and p. 417, and n. 64, p. 713, gives some further references on the status of Catholicism at this time in the British imagination, and on comparisons drawn with Buddhism; the fullest account of the comparison, which may be traced in British sources well back into the eighteenth century, may be found in Philip C. Almond, The British Discovery of Buddhism (Cambridge: Cambridge University Press, 1988), pp. 123-6.

${ }^{44}$ Robert Fortune. Three Years Wanderings in the Northern Provinces of China (London, New York, Bahrain: Kegan Paul, 2001 reprint of London: John Murray, 1847, second ed.), p. 176 .

${ }^{45}$ Fortune, Wanderings, p. 184 .

${ }^{46}$ Fortune, Wanderings,p. 177; cf. Ricci/Trigault, Histoire, p. 161. 
observations were inevitably made within the framework of their own beliefs, but they do often possess the benefit of the immediacy that was perhaps more fragile than we might at first realise. This can be readily illustrated by the second edition of the writings of the American, Justus Doolittle (1824-1880), which most social scientists today consult in reprints of the first, New York edition of 1865 . If we consult, however, the London, 1868 , edition prepared by a British fellow clergyman, Paxton Hood (1820-1885), we can see that the armchair was still the favoured position from which to comment on matters anthropological. Doolittle's writings have the considerable merit of telling us what he saw without too much interpretation. $\mathrm{He}$ carefully states, for example, that 'There are three classes of native priests in China, understanding the word "priest" to denote a person who officiates in religious worship'-thus threatening to anticipate the great French sinologist Henri Maspero (1883-1945), who with a certain amount of justification saw membership of the 'three religions' of China as forming very much a minority amongst Chinese believers, effectively restricted as it was to their professional clergy or their equivalents. ${ }^{47}$

At this point, however, Paxton Hood weighs in with a footnote, gleaned from a Catholic missionary, Evariste-Regis Huc (1813-1860), who had certainly travelled much further in China than his Protestant contemporaries, but whose writings sound a familiar note: 'Religious discussions have entirely ceased, and the whole Chinese nation has proclaimed this famous formula, with which everybody is satisfied, "San-kio-y-koio," - that is, "the three religions are but one". Thus all the Chinese are at the same time partisans of Confucius, Lao-tze, and Buddha, or rather they are nothing at all; they reject all faith, all dogma, to live merely by their more or less depraved and corrupted instincts.'- the very argument for religious syncretism leading to atheism voiced by Ricci. ${ }^{48}$ Naturally Hood, and in all probability Huc

${ }^{47}$ Henri Maspero, trans. Frank Kierman, Taoism and Chinese Religion (Amherst; University of Massachusetts Press, 1981), p. 78, translating an essay originally published in 1928. Even Maspero, however, sees this situation as the outcome of religious decline, and ignores the persistence of both a Buddhist and a Taoist laity.

${ }^{48}$ Justus Doolittle, Social Life of the Chinese (London, New York, Bahrain: Kegan Paul, 2002, reprint of London, 1868 edition), p. 182. It should be noted that Doolittle himself was well aware from observation of the simplifications imposed by the accepted tripartite scheme. Thus he later observes (p. 285): 'There is, however, another religion, using that term in a modified sense, which is properly and distinctively called the Religion of the State...' 
as well, did not know that where thinkers of Ricci's time had sought to reconcile the three teachings, they actually ended up creating a religious movement of a highly distinctive sort that survives to this day quite independently of the three other traditions. ${ }^{49}$ And far from endorsing the observations of Huc and Ricci, one of the most well read (and unduly neglected) Victorian researchers, alluded to below, by contrast commented somewhat later on the remarkable lack of syncretism in China in comparison with what might be expected in the light of the historical experience of other societies. ${ }^{50}$

In a subsequent note Hood, however, specifically avers that most of his readers will probably be unaware of the achievements of Ricci and his successors, but he has read about them in three sources, including 'an able paper on "Christianity in China," Foreign Quarterly Review, 1830'.51 This last piece evidently made quite an impression on him, for we find it already in an earlier footnote to Doolittle's description of Confucianism, which the American describes as having religious aspects, though this did not disbar the learned men who followed it from practising either Buddhism or Taoism at the same time, or permitting their families to do so. Paxton Hood interjects a correction on the basis of his reading affirming that 'Subsequent [sic] inquiries, however, appear to prove that the doctrine of Confucius, like that of Spinoza, is a kind of philosophical pantheism, from which all religion, properly speaking, is necessarily excluded'. ${ }^{52}$ So for at least one Victorian mind early written authority seemingly overrode any ethnographic observation.

Checking back to his source, however, reveals something even more bizarre, for the remark turns out to be a literal quotation from the essay 'Christianity in China', a review (unsigned, alas, like all contributions to the periodical in which appears) dealing with the eight volumes of Nouvelles lettres édifiants des missions de la Chine et des Indes Orientales, published in Paris in 1818-23. ${ }^{53}$ In the original

${ }^{49}$ On this group, see the recent studies by Judith A. Berling, The Syncretic Religion of Lin Chao-en (New York: Columbia University Press, 1980), and Kenneth Dean, Lord of the Three in One: The Spread of a Cult in Southeast China (Princeton: Princeton University Press, 1998)—and note in particular Dean's concluding remarks on the continued vitality of this group today.

${ }^{50}$ See below, n. 98, for this figure, Sir Arthur C. Lyall.

${ }^{51}$ Doolittle, Social Life of the Chinese, p. 622.

52 Doolittle, Social Life of the Chinese, p. 197.

${ }^{53}$ On this series, see the entry in John Lust, Western Books on China Published up to I 850 (London: Bamboo Publishing, 1987), p. 194. 
context the word 'subsequent' distinguishes the earlier Jesuit opinion from that of the first secular sinologist in France, Jean-Pierre AbelRémusat (1788-1832), one of whose works is specifically cited. But this extended synopsis of eighteenth-century Jesuit knowledge, used a generation later by Doolittle's editor, is generally content to report without comment the time-honoured analyses provided by its source: '...we shall briefly describe the three religious sects into which the vast population of this empire is divided. These are the sect of Confucius, the sect of Lao-tseu, and the sect of Buddha'. ${ }^{54}$ The detailed characterizations of the three are in fact only substantially modified by further reading in the case of Confucianism, for the tradition said to have been founded by Laozi, as we might have guessed, is quite straightforwardly described: 'His disciples degenerated into a sect of jugglers, magicians and astrologers' ${ }^{55}$ The only original note in this case is struck a little later: 'It must be from this sect that the Jesuit missionaries have experienced most opposition, for they denominate them an "abominable sect"...', a speculation well in line with the contemporary suspicion of Jesuit motives that has already been mentioned. ${ }^{56}$ On Buddhism, by contrast, the reviewer admits to complete bafflement, probably because-again as the footnotes indicate-an increasing volume of contradictory material had by this point appeared in Europe, but nothing that clarified the Buddha's actual position in history. ${ }^{57}$

Doolittle, unlike Hood, may perhaps have had the advantage of not having read much before reaching China: his work reveals, for example, that he had no knowledge of French, and that he was obliged to communicate with French missionaries in Mandarin. ${ }^{58}$ Few British

54 Thus 'Christianity in China', p. 488, in Foreign Quarterly Review V (183o), pp. 485 $5^{16}$; one should note, moreover, that the comparison of Confucianism with Spinoza has been seen as already trite a full century before this date: note the editorial comment in Joseph Spence, ed. James M. Osborn, Observations, Anecdotes and Characters of Books and Men,Volume One (Oxford: At the Clarendon Press, 1966), p. 299, on anecdote no. 733 .

55 'Christianity in China', p. 489.

56 'Christianity in China', p. 490.

${ }^{57}$ Almond, British Discovery of Buddhism, pp. 54-6o. Eventually a type of awareness of Buddhism penetrated beyond academic circles to a wider readership in later Victorian times, as has been demonstrated more recently by J. Jeffrey Franklin, 'The Counterinvasion of Britain by Buddhism in Marie Corelli's $A$ Romance of Two Worlds and H. Rider Haggard's Ayesha: The Return of She', Victorian Literature and Culture (2003), pp. 19-42, a study that incorporates more recent research into perceptions of Asian religion in Britain than that first ventured by Almond.

${ }^{58}$ Doolittle, Social Life of the Chinese,p. 631. 
missionaries were so fortunate, with the result that insight always seems, as with Fortune, to be struggling against the 'armour of false facts' (to quote a phrase from a British resident in Republican times) in which they arrived. ${ }^{59}$ Thus John Henry Gray (1828-189o) affirms the ancient Chinese knowledge of God, and blames Buddhism and Taoism for promoting new gods in competition: 'Not to be outdone by their rivals, the Buddhists, who could point to Shakyamuni as deity incarnate, the Taouist priests deified Laou-tsze, and the two sects rivalled each other in providing gods of every kind for the wants of the people. Whenever popular sentiment seemed to indicate that it was ripe for such a step, a new god was provided, either by the deification of a hero, or the personification of a principle, or social element, such as wealth, war, and longevity' ${ }^{60}$ Yet a little further down the page he states 'The priests of the sect of Taou are very numerous, and appear to constitute the whole of its professed disciples', while popular religion is treated in a separate chapter, in which it is remarked of the Chinese 'Their religion is essentially a cultus', thus drawing once more quite a helpful implicit analogy with the religious situation in Roman times-though such analogies were not invariably positive in their results, since the diplomat Sir Thomas Wade (1818-95) while perceptively noting the predominant importance of 'cults' to Chinese religion, unambiguously declared them 'puerile idolatry'. ${ }^{61}$ John Arthur Turner (in China 1886-1891) like Grey follows tradition in stating that 'Besides Confucianism, Taoism and Buddhism, usually spoken of as the Three Religions of China, there are about twenty millions of Mohammedans in the Empire...6 ${ }^{62}$ Even so he shows a worrying degree of creativity in inventing Taoist history a priori where knowledge fails him: 'When the Confucian books were burnt and the scholars buried alive, the Taoists had a clear field for two hundred years. Superstition now ran riot'. ${ }^{63}$ Yet the Taoists are not blamed

59 The phrase is cited from the novelist Stella Benson (1892-1933) by Robert Bickers, Britain in China (Manchester: Manchester University Press, 1999), p. $5^{8 .}$

${ }^{60}$ John Henry Gray, China: A History of the Laws, Manners and Customs of the People (Mineola, NY: Dover, 2002, reprint of London: Macmillan \& Co., 1878), pp. 75, 99.

${ }^{61}$ Grey, China, pp. 99, 143; Wade is quoted in Arthur H. Smith, Chinese Characteristics (New York: Fleming H. Revell, 1894), p. 3o6, but I have not located the source.

${ }^{62}$ John A. Turner, Kwang Tung or Five Years in South China (Hong Kong: Oxford University Press, 1982, reprint of London: S. W. Partridge \& Co., 1894), p. 65 .

${ }^{63}$ Turner, Kwang Tung, p. 53. 
for everything: 'It is thought that Buddhism helped to obliterate the native Chinese conception of one supreme God. ... ${ }^{64}$

But besides such works ostensibly giving primacy to observation, and hence reprinted in our own times, we should not overlook other means by which a supposed knowledge of Chinese religion was diffused, through lectures by missionaries temporarily or permanently returned to Britain, and through the simultaneous existence of more modest volumes designed either for the edification of missionary supporters or for the education of those now drawn towards the comparative study of religion-volumes that do not hesitate to name their sources, even where the authors could claim some personal experience of China themselves.

Lectures on religion, unless based on a series and subsequently collected and published in monographic form, no doubt had less impact in print, so perhaps one example, from the Journal of the Transactions of the Victoria Institute, will suffice, in that it shows especially from the audience discussion what ideas had taken an unassailable hold on British minds by the start of the twentieth century. Speaking in 1904 in a funded series on the religions of the East, the 'Long Lectures', Arthur Elwin, charged with introducing China into the series for the first time, starts with 'Ancestor Worship', assuring the audience on the basis of his missionary experience in China that this is something subscribed to by 'Confucianism, Buddhism, and Taouism'. In response, another missionary, F. Storrs Turner, first insists on the original lack of ancestor worship and pure monotheism of the Chinese, concluding against the then current ideas of Herbert Spencer on the evolution of religion 'there is no measuring the gulf between spirits and God'. On the contemporary religion of the 'Chinaman' he then observes: 'It is a mixture of Confucianism, Buddhism and Taouism. He believes everything in a way, but hardly anything in reality'. These opinions, not expressed by Elwin, evidently found favour with the rest of the audience, one member of which is quoted as saying 'We are all agreed on this-that all worship began with a knowledge of the true God, and every form of idolatry and superstition is some corruption of a deviation from the true path, which is not Herbert Spencer's idea of evolution of religion by degrees'. In a Parthian shot Storrs Turner finally remarks of ancestor worship: 'It is in a corrupt stage at the

${ }^{64}$ Turner, Kwang Tung, p. 64 . 
present time, no doubt'. ${ }^{65}$ And no doubt had Matteo Ricci been in the audience, he would have applauded the general sentiments of the meeting quite heartily, even if the last specific point was not a belief of his, but of his later detractors in rival Catholic missions. ${ }^{66}$

As for single volumes, we have already mentioned one of them, by A. E. Moule, from 1871 . He prefaces his list of authorities with the words 'The three religions of China, the only three which we need specially analyse, are the Confucian, Buddhist, and Taouist creeds' ${ }^{67}$ But a few pages later he states 'There is a class of objects for religious worship, which are, properly speaking, neither Buddhist nor Taouist, but native gods, tutelary deities, patronised nevertheless, and adopted into the pantheons of either sect', a proposition that remarkably, in view of what we have read elsewhere, excludes Buddhist or Taoist agency in the creation of new cults. ${ }^{68}$ That such an insight was somewhat difficult to achieve in the prevailing climate is suggested by a similar work by William Muirhead (1822-1900), published in 1870, that names Doolittle amongst its authorities. ${ }^{69}$ Here we find the all too familiar story: of Taoism, he remarks 'Originally there was no idolatry or superstition connected with it, but it became notorious in this respect; and we find the old theology of China as taught in the classic books, and illustrated in the existing state ritual, perverted and abused in an extreme degree'. ${ }^{70}$ And in another distant echo of Ricci: 'The Confucian philosophy has greatly modified the influence of the current idolatry, and tended to produce a widespread feeling of infidelity and indifference about it'. ${ }^{71}$ Both Moule and (more circumspectly) Muirhead agree, it should be noted, with Ricci's line of interpretation in seeing the ancient religion inherited by Confucius as 'preserving, though in a clouded form, the ancient faith in one true God' ${ }^{72}$ This notion, however, stirred considerable controversy in Protestant circles at this time when taken up and acted upon symbolically by James Legge, as Norman Girardot documents in some detail. ${ }^{73}$

${ }^{65}$ Arthur Elwin, 'Ancestral worship', Journal of the Transactions of the Victoria Institute, 36 (1904), pp. 66-84.

66 Porter, Ideographia, p. 119.

67 Moule, Four Hundred Millions, p. ${ }^{5} 5$.

${ }_{68}$ Moule, Four Hundred Millions, pp. 33-4.

${ }^{69}$ William Muirhead, China and the Gospel (London: James Nisbet \& Co., 1870), p. 146 .

${ }^{70}$ Muirhead, China and the Gospel, pp. 83-4.

${ }^{71}$ Muirhead, China and the Gospel, p. 103.

${ }^{72}$ Moule, Four Hundred Million, p. 3o; cf. Muirhead, China and the Gospel, pp. 80-1.

${ }^{73}$ Girardot, The Victorian Translation of China, pp. 87-8; see also pp. 277-8 for some further repercussions. 
By contrast to Muirhead's use of missionary observers like Doolittle, the ex-consular official turned academic, Robert K. Douglas, lists a somewhat different set of authorities in the Preface to his contribution to comparative religion, a work which dates originally to 1879 but was successful enough to be reissued in 1895: here missionary authorities like Legge jostle with books by the French academic sinologist Stanislas Julien $\left(\mathbf{1}^{1799-1873)} \cdot{ }^{74} \mathrm{He}\right.$ is even so in agreement with Moule and Muirhead in cautiously opining 'In all probability there was a time when the worship of Shang-te was the expression of the pure monotheistic faith of the Chinese'. ${ }^{75}$ And he is equally damning about Taoism, though in commenting on the stretch of history we have seen imaginatively filled in by Turner he offers an intriguing alternative in some detail, but unfortunately not detail derived from historical sources: 'At this time Taouism was in no sense a religion, and exercised no control over the conduct of its votaries. The court of the emperor Woo was too often the scene of the grossest immorality, and Taouist writers recount without shame the legendary amour of the emperor with his fairy visitor Se Wang Moo" ${ }^{76}$ That believing this to have been the actual history of Taoism involved him believing in fairies seems to have troubled him not one whit, though he does hesitate a little in ascribing every popular Chinese cult (such as those devoted to the gods of wealth, rank. happiness and old age) to the Taoist tradition: 'It will be observed that there is nothing distinctively Taouist in the worship of these gods except the gross superstition that accompanies it.... ${ }^{77}$ This persistence in ascribing the bulk of Chinese religion to Taoism on the grounds that one finds both distasteful almost threatens to carry over in the twentieth century into much less derogatory authors, such as William Soothill (1861-1935), whose work The Three Religions of China of 1913 was to become a much reprinted classic, remaining in bibliographies well into the second half of the twentieth century. ${ }^{78}$

It may be that Soothill's comparative politeness was caused by lack of time in what was originally a limited lecture series-'Time fails to tell in detail of the downfall of Taoism', he remarks in passing; it may

${ }^{74}$ Robert K. Douglas, Confucianism and Taouism (London: Society for Promoting Christian Knowledge, 1895), Preface.

${ }^{75}$ Douglas, Confucianism and Taouism, p. 12.

${ }^{76}$ Douglas, Confucianism and Taouism, p. 241.

${ }^{77}$ Douglas, Confucianism and Taouism, p. 283 .

78 The slightly revised 1923 edition (cited below) is listed in the bibliography of the 1985 reprint of D. Howard Smith, Confucius and Confucianism (London: Paladin Books, 1974), p. 237. 
equally be that a new and more conciliatory mood was beginning to affect the missionary world that formed his scholarship. ${ }^{79}$ But structurally his views are still rather similar, even whilst he comes up with a somewhat different solution: 'For convenience sake I have included what we might almost call the fourth religion of China, namely the deification of national worthies and their appointment as tutelary divinities under the heading of Confucianism. In reality we may consider the origin and development of this cult as largely due to Taoist influence, even though Taoists, equally with Confucianists, lay no claim to those divinities as their own' ${ }^{80}$ This evident problem aside, Soothill's analysis is not unsophisticated: he speaks in a qualified way of three 'recognised' religions, admits the usefulness of the word 'cult', and remarks on the importation from Japan of the modern word for religion, explaining that the term he translates by the word (i.e.jiao) does not quite match 'our' idea of religion. ${ }^{81}$ And certainly by 1932 not everyone felt happy with the sort of vituperation of Taoism offered by Douglas: a summary by B. S. Bonsall, covering the same ground as the Douglas volume, now appends a much lengthier bibliography, including several Chinese authors who were then starting to publish in English, and while some typical invective is quoted from Douglas himself ('the modern Taoists have sunk lower in the estimation of their fellow-men than any but the most degraded of idolaters'), this is balanced by the quotation also of some more recent and positive words on the matter from Lionel Giles $\left(1875^{-1958)} .^{82}\right.$

But Taoism was by no means safe, even at this point, despite the disappearance at last from twentieth-century discourse on Chinese religions of unhelpful terms like 'sect'. On of the most obtuse descriptions of the supposed corruption of Taoism that I have been able to find-a description so wrongheaded as to defy any quotationoccurs in the $195^{6}$ edition of a work on world religions and their founders first published in North America in 1929 by one Joseph Gaer. Suffice it to say that in entitling his piece 'Taoism: The Religion Few Can Understand' he was not (as I naively thought when I first saw the entry in a bibliography) trying to convey that only one or two Western pioneers like Maspero were making any headway with

${ }^{79}$ W. E. Soothill, The Three Religions of China (Oxford: Oxford University Press, 1923), p. 73; Lian Xi, Conversion of Missionaries, tends to place the softening of missionary attitudes somewhat later, after the outbreak of world war in Europe.

${ }^{80}$ Soothill, Three Religions, p. 75 .

${ }^{81}$ Soothill, Three Religions, pp. 11 , 14-15.

${ }^{82}$ B. S. Bonsall, Confucianism and Taoism (London; The Epworth Press, 1934), p. 120 
research, and that more study was needed. Quite the opposite: Taoism in China was so corrupt that few Chinese understood what it was about, unlike (it would seem) the much more enlightened Mr. Gaera breathtaking example of Orientalism in its purest form. ${ }^{83}$ Gaer's work, which was evidently designed to be used as a textbook, at least shows loftily ecumenical intentions in locating what it takes to be the best in Taoism. Alternative educational works available at the time still sometimes strike a far less positive note. John B. Noss, a Professor of Philosophy and author of a contemporary and rival work evidently aimed at college students, Man's Religions, writes in what will now be all too familiar terms 'Whether the final product of Taoist religionmaking should be called Taoist in any proper sense of that word is a question, but the Taoist priests had no hesitation, assured that since the common people shared in the decision as to which of the spirits, old and new, should be the most important to them, there was no need to hold back', while a couple of pages later he refers to twentieth-century Taoism as 'voodooism', a solely pejorative term at the time. ${ }^{84}$

The end of this lengthy tradition of Taoism-bashing on the grounds of its supposed degeneracy, first started by Ricci, only seems to have come as late as 1970, when Daniel Overmyer, one of the American pioneers of the study of Chinese religion as a separate subject area, took to task D. H. Smith for his remarks on the topic in his review of Smith's 1968 survey entitled Chinese Religion. Smith had been born in 1900 and spent twenty years as a missionary in China before teaching Chinese religion as a Lecturer in Comparative Religion at Manchester between 1953 and his retirement in 1966; Overmyer draws particular attention to his characterization of the religion of the people as 'a strange mixture of crude animistic beliefs, the cult of ancestors and ideas incorporated from Confucianism, Taoism, and Buddhism' and his statement that most Taoist priests 'are little more than ignorant charlatans'. ${ }^{85}$ To be fair, however, Smith's remarks on the Taoist priesthood allows at least that there were some exceptions, while he

${ }^{83}$ Joseph Gaer, How the Great Religions Began (New York: Dodd, Mead \& Company, $195^{6)}$, pp. 149-68.

${ }_{84}$ John B. Noss, Man's Religions (New York: The Macmillan Company, 1956), pp. 334,336 .

85 The details of Smith's career are drawn from the biographical note prefixed to Confucius and Confucianism;for Overmyer's criticisms, see p. 257 of his review of Smith's Chinese Religions in History of Religions 9.2/3 (November 1969/February 1970), pp. 256-6o: Overmyer's quotation, from p. 111 of the American edition (New York: Holt, Rinehart \& Winston, 1968), may be found on the same page in the equivalent British edition (London: Weidenfeld and Nicholson, 1968). 
explicitly follows Maspero (using a 1933 translation into English of the essay already cited above) in seeing 'popular religion' as a force in its own right rather than as a mere appendage to the three teachings. ${ }^{86}$ And it was perhaps inevitable that Smith should have been a little behind the times-he was, after all, for most if not all of his teaching career the only scholar in the United Kingdom outside of departments of Chinese Studies lecturing on Chinese religion at all, whereas at the start of the twenty-first century numbers have soared to three times as many as in his day. But only in the 1970 did substantial research on both Taoism and on Chinese religion as observed critically by trained anthropologists start to appear in the English language, making it clear that Taoism could not be conflated with the sum total of popular cults into some debased and degenerate melange of formerly more coherent beliefs. ${ }^{87}$

One can admittedly point to one or two isolated anticipations of this breakthrough. Alan Elliot, in what was for his time a superb study of Chinese spirit-medium cults in Singapore, gives an enviably objective account of how Chinese religion as he encountered it actually worked, and even suggested the term 'Shenism', based on the Chinese word for a god or spirit, as a neologism far better descriptive of the beliefs of the majority of the Chinese than any term used hitherto. ${ }^{88}$ Even this term seems to have been anticipated by at least a generation in Korea, where Christian missionary observers, perhaps less hampered by their reading, seem to have put forward the equivalent Korean term to describe the very similar situation they found there. ${ }^{89}$ But Korea was another country as far as sinologists were concerned, and so no doubt was Singapore, at least in the eyes of American social scientists, who in the 1960 s at least appear to have ignored Elliot's work. ${ }^{90}$

${ }^{86}$ Smith, Chinese Religions, p. 172.

87 The beginnings of scholarship on Taoism are reviewed in the introduction to Maspero, Taoism and Chinese Religion; amongst works of anthropology, the collective volume produced by Arthur P. Wolf (ed.), Religion and Ritual in Chinese Society (Stanford: Stanford University Press, 1974) stands out as a particular milestone; Girardot, Victorian Translation, p. $5^{\mathbf{1}} \mathbf{5}$, points also to the importance of C. K. Yang's work, Religion in Chinese Society (Berkeley and Los Angeles: University of California Press, $1961)$ and to a general change in the intellectual climate.

${ }_{88}$ Alan J. A. Elliot, Chinese Spirit-medium Cults in Singapore (London: Department of Anthropology, London School of Economic and Political Science, 1955), p. 29.

${ }^{89}$ David Chung, Syncretism; The Religious Context of Christian Beginnings in Korea (Albany, NY: State University of New York Press, 2001), p. 92, appears to give the credit for this to the Protestant pioneer H. G. Underwood, writing in 1910.

${ }^{90}$ There is no mention of Elliot, at any rate, in the work of C. K. Yang, Religion in Chinese Society. 
Looking back, however, over the material cited, it becomes apparent that the problem confronting earlier generations was not necessarily a lack of accurate observation: Ricci, for example, specifically talks of 'sects' in the books of the Chinese, signalling clearly that he is talking exclusively of textual traditions; Davis talks of 'religious or philosophic systems', probably signalling that he was not entirely comfortable with Confucianism being straightforwardly labelled a religion. The main conceptual problem seems to have been in making sense of the data gathered in the absence of any careful research into the history of religion in China. Lacking this, writers like Turner and Douglas were eventually driven to constructing imaginary bits of history on a priori principles, basically no more than the principle of presumed decline, the same so-called 'Protestant presuppositions' (albeit in this case in a version produced by Counter-Reformation thinkers) that elsewhere have been seen as affecting our understanding of Buddhism also. ${ }^{91}$

For in fact there is no more reason to give any logical or historical priority to the 'three teachings' than there is to presume an original Chinese monotheism. There is no point in denying the importance of these three traditions, with their strong textual and other influences in East Asia: as an assembly of three different strands, they were even able to inspire another conceptual grouping in Japan, where Buddhism, Shinto and Confucianism were regarded as the local equivalent. ${ }^{92}$ But although some seem to have assumed that the original Chinese threesome appeared as it were automatically as soon as Buddhism became part of the Chinese environment, the historical evidence actually points in a very different direction. ${ }^{93}$ It clearly took some time before Buddhism was seen as a coherent and self-organised religion under the name 'teaching of the Buddha', rather than as just another, but somewhat exotic, cult of a dead hero, and my own belief is that Taoism was only able to achieve a like level of coherence with the example of Buddhism before it. ${ }^{94}$ As for Confucianism, it may long

${ }^{91}$ Gregory Schopen, 'Archaeology and Protestant Presuppositions in the Study of Indian Buddhism', in Gregory Schopen, ed. Donald S. Lopez, Jr., Bones, Stones, and Buddhist Monks: Collected Papers on the Archaeology, Epigraphy, and Texts of Monastic Buddhism in India (Honolulu: Hawaii University Press, 1997), pp. 1-22.

${ }_{92}$ On this see Inoue Nobutaka, ed., Mark Teeuwen and John Breen (trans.), Shinto-A Short History (London: Routledge/Curzon, 2003), p. 110.

${ }_{93}$ Once again, we may point for a negative example to D. Howard Smith, Confucius and Confucianism, p. $14^{1}$.

${ }^{94}$ For a preliminary sketch of this view, see my remarks in Ropp, Heritage of China, pp. $145,148-9$. 
have been a self-aware cultural tradition, but over the course of time it only moved partially towards the same model.

For this reason it may be legitimate to wonder if we have even yet freed ourselves today from the grip of the illusion described so far, when one of the latest introductory surveys of Chinese religion divides its material up without reserve by stating 'In this book the three teachings and popular religion will therefore comprise the four central "traditions" to be examined', even though one can understand the pedagogic pressures leading to such a statement. ${ }^{95}$ First, a simple dichotomy between the three textual traditions and the rest seems to ignore the various intermediate third levels that may be detected in between, though the materials surveyed so far largely ignore this problem. ${ }^{96}$ Secondly, a simple dichotomy ignores the way in which the state could intervene in the realm of the non-text based cults, something that several of our authors, such as Robert Douglas and William Soothill seem to worry about, without quite finding a satisfactory solution to what they evidently felt was a problem. Here a little historical knowledge could have been useful, too, in that though a certain restricted range of religious observances fell within the scope of the Confucian cultural tradition, the Chinese state eventually broadened its patronage of local religion in a way that went beyond the conventional bounds of that tradition, but without necessarily involving Taoism either; other cults, while tolerated, showed a considerable spirit of independence from authority. ${ }^{97}$ To give credit where it is due, however, one particularly astute scholar, Sir Arthur C. Lyall (1835-191 1), was able to identify the quite unusual importance of the state in Chinese religion without much help from the scholarship of his age. ${ }^{98}$ But a third point that should also be added

${ }^{95}$ Joseph A. Adler, Chinese Religions (London and New York: Routledge, 2002), p. 14 .

96 Thus Edward L. Davis, Society and the Supernatural in Song China (Honolulu: University of Hawaii Press, 2001), pp. 6-7, proposes a three layer vertical division of late imperial religion; cf. also my remarks in Ropp, Heritage, p. 156 .

${ }_{97}$ On state intervention in the world of local religion, see notably Valerie Hansen, Changing Gods in Medieval China, I I 2 7-I 276 (Princeton; Princeton University Press, 1990), and for one example of a cult figure of a somewhat ambivalent character, Meir Shahar, Crazy Ji: Chinese Religion and Popular Literature (Cambridge. MA: Harvard University Press, 1998).

98 On Lyall, see the remarks of Maurice Freedman in Wolf, Ritual and Religion in Chinese Society, pp. 21-3; his essay on China in his Asiatic Studies, Religious and Social (London: Watts \& Co., 1907), pp. 79-110, deserves republication and commentary just as much as the proto-ethnographic writings of missionary scholars. 
is that our own age finds notions like 'popular' somewhat suspiciously non-analytic in any case, and prefers a more careful consideration of what may turn out to be several quite different forms of religion rather than an undifferentiated rag bag. ${ }^{99}$

If we do wish to move definitively beyond the underlying paradigms bequeathed by earlier scholarship, it is surely necessary to abandon once and for all the static models of varieties of Chinese religion that tended to be constructed in ignorance of the complex developments of Chinese religious history. It simply will not do in the light of a knowledge of history to understand the religious situation of China at any time, up to and including the present, as something static or passive, like a cake that may be sliced in various ways but is only gradually susceptible to change and decay of a purely negative kind. Somehow we must come up with descriptions of Chinese religion that are dynamic and organic, and that can cope with constantly shifting patterns of development. We cannot blame Ricci and his colleagues for failing to do this: after all, though some sources providing historical information on the course of Chinese religious history were theoretically available to them, they were without exception partial and partisan, and it is only modern scholarship that has been able to draw on the full range of materials available, including (as noted above in the case of early China) newly available archaeological materials. But though the Jesuit founding fathers of European studies of China may rightly have been called a 'Generation of Giants', it is surely high time in the twenty-first century to step beyond their lengthy shadows. ${ }^{100}$

${ }^{99}$ For a judicious exploration of these issues, see Stephen S. Teiser on pp. 21-5 of his 'Introduction' in Donald S. Lopez, Jr., Religions of China in Practice (Princeton: Princeton University Press, 1996), pp. 3-37, an essay that as a whole provides an excellent summary of current perspectives.

100 The phrase is that of George H. Dunne, Generation of Giants: The Story of the Jesuits in China in the Last Decades of the Ming Dynasty (Notre Dame; University of Notre Dame Press, 1962). 